The First World War necessitated not only the mobilization of troops, but the industrial resources of all the Great Powers. This book analyses the political constraints and ramifications of industrial mobilization in Russia. It focuses on the War-Industries Committees, an organization founded in 1915 ostensibly to assist in the war effort but also incorporating the aspirations of the Russian industrial bourgeoisie for greater control over the administration of the war economy and, ultimately, political power.

Drawing on Soviet and Western archives, contemporary newspapers, the publications of the War-Industries Committees, and a wide range of monographic literature, the author pieces together the ways in which industrial mobilization became a highly charged political issue, one that contributed towards the downfall of the old regime. After an introductory chapter on the 'making' of the Russian industrial bourgeoisie, the author examines initial efforts to mobilize industry, the crisis which brought about the creation of a network of War-Industries Committees, and the challenge they posed to the Tsarist government. The next two chapters explore the Committees' involvement in war-industrial production and the regulation of the war economy. This is followed by a consideration of the workers' groups and their attempts to put industrial relations on a 'European' footing. A final chapter discusses the role of both the Committees and their workers' groups in the social and political upheavals which preceded the February Revolution, and their respective fates in 1917.

Dr Lewis H. Siegelbaum is a Senior Lecturer in History at La Trobe University, where he has been teaching since 1976 . He has written extensively on Russian social and economic history, and is engaged on a study of Soviet workers in the 1920s and 1930s. 
St Antony's/Macmillan Series

General editor: Archie Brown, Fellow of St Antony's College, Oxford

Archie Brown and Michael Kaser (editors) SOVIET POLICY FOR THE 1980s

S. B. Burman CHIEFDOM POLITICS AND ALIEN LAW

Wilhelm Deist THE WEHRMACHT AND GERMAN REARMAMENT

Ricardo Ffrench-Davis and Ernesto Tironi (editors) LATIN AMERICA AND THE NEW INTERNATIONAL ECONOMIC ORDER

Bohdan Harasymiw POLITICAL ELITE RECRUITMENT IN THE SOVIET UNION

Neil Harding (editor) THE STATE IN SOCIALIST SOCIETY

Richard Holt SPORT AND SOCIETY IN MODERN FRANCE

Albert Hourani EUROPE AND THE MIDDLE EAST

THE EMERGENCE OF THE MODERN MIDDLE EAST

A. Kemp-Welch (translator) THE BIRTH OF SOLIDARITY

Paul Kennedy and Anthony Nicholls (editors) NATIONALIST AND RACIALIST MOVEMENTS IN BRITAIN AND GERMANY BEFORE 1914

Richard Kindersley (editor) IN SEARCH OF EUROCOMMUNISM

Gisela C. Lebzelter POLITICAL ANTI-SEMITISM IN ENGLAND, 1918-1939

C. A. MacDonald THE UNITED STATES, BRITAIN AND APPEASEMENT, 1936-1939

Patrick O'Brien (editor) RAILWAYS AND THE ECONOMIC DEVELOPMENT OF WESTERN EUROPE, 1830-1914

Roger Owen (editor) STUDIES IN THE ECONOMIC AND SOCIAL HISTORY OF PALESTINE IN THE NINETEENTH AND TWENTIETH CENTURIES

Irena Powell WRITERS AND SOCIETY IN MODERN JAPAN

T. H. Rigby and Ferenc Fehér (editors) POLITICAL LEGITIMATION IN COMMUNIST STATES

Marilyn Rueschemeyer PROFESSIONAL WORK AND MARRIAGE

A. J. R. Russell-Wood THE BLACK MAN IN SLAVERY AND FREEDOM IN COLONIAL BRAZIL

Aron Shai BRITAIN AND CHINA, 1941-47

Lewis $H$. Siegelbaum THE POLITICS OF INDUSTRIAL MOBILIZATION IN RUSSIA, 1914-17

David Stafford BRITAIN AND EUROPEAN RESISTANCE, 1940-1945

Nancy Stepan THE IDEA OF RACE IN SCIENCE

Guido di Tella ARGENTINA UNDER PERON, 1973-76

Rosemary Thorp and Laurence Whitehead (editors) INFLATION AND STABILISATION IN LATIN AMERICA

Rudolf L. Tőkés (editor) OPPOSITION IN EASTERN EUROPE 


\section{THE POLITICS OF INDUSTRIAL MOBILIZATION IN RUSSIA, 1914-17}

A Study of the War-Industries Committees

Lewis H. Siegelbaum

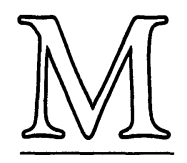

in association with

Palgrave Macmillan 
(C) Lewis H. Siegelbaum 1983

Softcover reprint of the hardcover 1st edition 1983

All rights reserved. No part of this publication may be reproduced or transmitted, in any form or by any means, without permission

First published 1983 by THE MACMILLAN PRESS LTD

London and Basingstoke Companies and representatives throughout the world

ISBN 978-1-349-17318-1 ISBN 978-1-349-17316-7 (eBook) DOI 10.1007/978-1-349-17316-7 
To my parents 


\section{Contents}

List of Tables

$1 x$

Preface and Acknowledgements

$\mathbf{x}$

Special Notes

xvi1

List of Abbreviations

xvi1i

1 Russian Industry and the Making of a

Russian Industrial Bourgeoisie

2 Russian Industrialists and the Initial

Mobilization, 1914-15

2.1 The patriotic enthusiasm of Russian industrialists

2.2 The munitions shortage of 1914-15

3 Moscow to the Rescue: the Formation of the War-Industries Committees

3.1 Riabushinskii and the mobilization of Russian industrialists

3.2 The district and local War-Industries Committees

3.3 The Central and Moscow War-Industries Committees

3.4 The First All-Russian Congress

4 The High Politics of Defence, JuneSeptember 1915

4.1 The War-Industries Committees and the Special Councils

4.2 The War-Industries Committees' triumvirate and the Progressive Bloc 
5 The War-Industries Committees and the Production of Military Supplies

5.1 The distribution of state orders

5.2 The contractors of the WarIndustries Committees

5.3 The War-Industries Committees' enterprises and the development of new industries

5.4 The fulfilment of orders

5.5 Conclusions

6 The War-Industries Committees and the Regulation of the War Economy

6.1 Metals and foreign purchases 123

6.2 Coal and oil 134

6.3 Cotton 142

6.4 Evacuation and rail transport 147

6.5 Manpower 151

6.6 Conclusions 156

7 The Labour Question - the Workers' Groups of the Mar-Industries Committees

7.1 Class collaboration vs 'boycottism'

7.2 The politics of industrial relations 170

8 The Challenge of Revolution 183

8.1 From patriotic despair to revolution 183

8.2 The War-Industries Committees from February to October 199

Conclusion 209

Epilogue 213

Notes $\quad 215$

Select Bibliography 284

$\begin{array}{ll}\text { Index } & 302\end{array}$ 


\section{List of Tables}

1.1 Strikes in Russia, 1910-14

3.1 Social composition of district and local committees, 1916

3.2 Composition of Central Mar-Industries Committee

5.1 The distribution and fulfilment of orders by the Central War-Industries Committee

5.2 Distribution of wartime orders, July 1914-May 1916

5.3 Regional distribution of contracts for articles ordered through the Central War-Industries Committee, 1 March 1916

5.4 Main articles ordered by the mechanical Committee, 1 February 1916

5.5 Contractors of Moscow War-Industries Committee located in Moscow province, 1915-16

5.6 Deliveries by Central Far-Industries Committee of selected articles, 1916 


\section{Preface and Acknowledgements}

The First World War, the Great War as it was commonly called before another cataclysmic struggle engulfed the world, took over 8 million lives and provoked social and political changes far exceeding almost everyone's expectations or fears. What made the 1914-18 war so destructive, and what at least in part accounts for the pressures for social and political change, was the unprecedented mobilization of industrial resources. That is, the very means by which the European powers increased their capacity to destroy each other also contained a threat to the ways of life and the political systems which those powers were attempting to defend.

In this sense, industrial mobilization represented a quickening of the pace of industrial development with all of its attendant dislocations and disruption. Whether the changes provoked by industrial mobilization could be contained within pre-existing structures or whether they would lead to social disorder and political revolution depended on the nature of the pre-existing order and that of the mobilization. No state could afford to rely solely on its coercive powers or its traditional methods to secure the loyalty and/or compliance of its population. Each resorted to an expansion of its bureaucratic apparatus. But entailed in that expansion was the representation of social interests and groups previously outside, or even hostile to, the state machinery. Hence, in France the Third Republic's union sacrée was achieved in part by the inclusion of four socialist ministers; the national coalition in Britain was forged in 1915 by the integration of business and trade union organizations into the state's 
administration of industry; and the near militarization of industry and labour in Germany was achieved by the extraordinary degree of cooperation between military, business and trade union leaders.

Among the Great Powers, this process of coopation was least developed in Russia during the war. Not only did the Tsarist regime fail to accommodate itself to working class representation, but even the middle classes and, particularly, large sections of the industrial bourgeoisie were denied access to the levers of state power and became rivals to the state's mobilization of industry.

The present study focuses on this rivalry. It analyses the politics of industrial mobilization in Russia through an investigation of the WarIndustries Committees. This was an organization of industrialists set up in mid-1915 to assist the state in its belated efforts to put Russia's economy on a war footing. The immediate inspiration for the creation of the committees was the shortage of munitions experienced by the Russian army. This shortage, which had existed since the outbreak of the war, took on crisis dimensions in the spring and summer of 1915 when the Russian armies retreated from Poland and Galicia. The momentum generated by that crisis soon spilled over into other questions of production and distribution. It raised serious doubts within the industrial bourgeoisie about the ability of traditional state contractors to furnish an adequate supply of war materials, the Tsarist bureaucracy to administer the war economy, and the very system of government to sustain the war effort. It thus became a political question, and, in so far as the mobilization of labour power was concerned, a social question as well. Even after the munitions shortage had been overcome - largely through means other than those advocated or represented by the War-Industries Committees - the crisis of confidence generated by the shortages continued, justifying the committees' existence and complicating the mobilization of industry.

The significance of the War-Industries Committees, then, was not limited by their role in the production and distribution of war materials, though in this respect they contributed more than 
has hitherto been acknowledged. The world of the committees was a microcosm which reflected the most profound issues of Russian industrial life. The state's guardianship of industry, the policies of its regulatory agencies, the development of new products and processes to overcome dependence on foreign technology, the relationship of technical specialists to industrial development, and the necessity to forge links with the working class these were just some of the concerns raised by the committees. In addition, representing the most politically dynamic elements within the industrial bourgeoisie, the committees were frequently in the forefront of the liberal opposition movement. As such, their fate was intricately bound up with the changing fortunes of the Duma's Progressive Bloc and its campaign to establish a 'government of public confidence' with the February Revolution, and with the Provisional Government in which several of the committees' leaders served as ministers. Finally, the committees' sponsorship of working class representation in the form of autonomous workers' groups added a new dimension to relations between the liberal and social democratic movements, one which in important ways prefigured the experience of 1917 .

There has previously been no full-length study of the War-Industries Committees. Soviet historians dealt fleetingly with them in the 1920s and 1930s in connection with the publication of memoirs by ex-Tsarist military and civil officials, and of the bulletins of, and other materials relating to, the workers' groups.[1] This, the inter-war period, also saw the publication by the Carnegie Endowment Fund of a number of studies by émigré academics and journalists of a liberal persuasion. These were, in the main, far more sympathetic to the War-Industries Committees and the other major public organizations, the Union of Towns and the Zemstvo Union.[2] Those shortcomings in their activities that were acknowledged were generally attributed to the Tsarist government's refusal to share or devolve its authority.

On the eve of the Soviet Union's involvement in the Second World War appeared the only comprehensive article ever published in the USSR on the War-Industries Committees.[3] The aim of the 
article was to demonstrate that the committees' contribution to the war effort was negligible and that their main function was the political mobilization of the Russian bourgeoisie against the rising tide of worker unrest. This argument, which became the touchstone for many subsequent studies bearing on the committees, rested on weak ground a speech given at the committees' second congress, a quotation from the chairman of the central committee referring to tactics adopted by liberals in 1913, and other slightly misleading information. [4] No archival material pertaining to the committees was used.

The Soviet victory in the Second World War invited comparisons with the less successful performance of the Tsarist state and warindustrial production in 1914-17. A dissertation submitted in 1947 by N.I. Razumovskaia analysed the Central War-Industries Committee's economic activities in considerable depth and on the basis of extensive archival material. [5] However, the author neglected to discuss several important questions, such as the relationship of the central committee in petrograd to the provincial committees, the preparations for post-war development, the role of technical specialists, and the issues raised by the workers' groups.

The administration of the economy in the first World War and its shortcomings attracted a good deal of attention in the post-Stalin years. A.L. Sidorov's numerous articles and K.N. Tarnovskil's study of the metallurgical industry contain many insights into the conflicts between the government and the committees and among industrialists.[6] Much of their work was based on archival material still unavailable to Testern scholars. The considerable debt which I owe to these historians' works is acknowledged, especially in Chapters 2 and 6 .

In 1967, the fiftieth anniversary of the February and October Revolutions, two Soviet historians, V.Ia. Laverychev and V.S. Diakin, gave the committees prominence in their studies of the political activities of the Russian bourgeoisie.[7] Diakin's in particular is a characteristically judicious and closely argued work. But neither book attempts to link political strategies and fortunes with industrialists' roles in the war 
economy. Of great interest also, as much for the questions it poses as for the provocative conclusions which it draws, is George Katkov's Russia 1917: The February Revolution, also published in 1967.

While Soviet historians have written extensively on the internal composition of the Russian bourgeoisie, this question has only recently attracted attention among Western scholars. In particular, the degree of conflict between Moscow and Petersburg industrialists has been the subject of an interesting debate, with one contributor viewing the Central War-Industries Committee as 'the chief battleground for the struggle' during the war years.[8]

More recently still, two works have appeared which deal with issues raised in the present study. One, by Raymond Pearson, concentrates on the manoeuvrings of the parties within the Progressive Bloc. Its chief value is in detailing the dilemmas of the Russian 'moderates' and their inability to transcend the 'crisis of Tsarism'. [9] The discussion of the industrial bourgeoisie and the War-Industries Committees unfortunately is marred by a number of inaccuracies. Pearson's failure to differentiate among 'industrialist circles', his frequent and puzzling references to the state's intention to 'nationalize' war industries, and his placement of the Central WarIndustries Committee in Moscow suggest that for him industrialists and industrial mobilization were not central concerns.

Norman Stone's book, The Eastern Front, 19141917 , is another matter entirely. It is, in many ways, a model of military and political history. Interpreting the impact of the war 'not as the vast run-down of most accounts but as a crisis of growth - a modernisation crisis in thin disguise', Stone convincingly disposes of a number of legends concerning the effects of backwardness and military unpreparedness on the war effort.[10] When he comes to consider the role of the War-Industries Committees, however, stone's revisionism (that is, his attempt to counter the claims of 'their propagandists') goes too far. He argues, for example, that 'where they succeeded they were unnecessary, where they did not they were a nuisance', and concludes that 'the War-Industries Committees 
appeared to be almost parasitical'.[11] But barely concealed in such statements, and indeed throughout much of the book, is a statist bias which is as one-sided in its way as are those of the committees' 'propagandists' and their liberal sympathizers abroad in theirs.

The point is that what was a nuisance for some was a patriotic duty for others. The crisis of modernization, exemplified and exacerbated by the politics of industrial mobilization, was at root a crisis of legitimacy. Characteristic of the crisis were different and mutually exclusive definitions of what was in Russia's interests, what the future of Russia should be, and, indeed, who was to determine it. The reader should perhaps be reminded that Russia is not the only country where such a crisis has existed or where it was resolved by forces antithetical to both contending parties.

A word about primary sources is in order. The committees' own newspapers and occasional publications were directed toward influencing public opinion in their favour. They have been used with great caution. Where possible, I have attempted to corroborate their information with press reports or other sources, recognizing that these too contain biases. Memoir material pertaining to the committees is almost non-existent.[12] I have, therefore, been particularly fortunate to have had access to a large body of archival material while I was an exchange student in the Soviet Union (1973-4). To the best of my knowledge, I am the first Western scholar to have consulted several of the archival fondy listed in the bibliography.

For this privilege, I am grateful to the International Research and Exchanges Board for sponsoring my year of study in the Soviet Union, to the Soviet Archival Administration, and to Professor V.I. Bovykin, my faculty supervisor in Moscow. I am also indebted to the curators of the Bakhmetev Archive at Columbia University (formerly the Archive of Russian and East European History and Culture) for permission to read and cite from its valuable collections; to Dr J.E.O. Screen, former Director of the Library of the School of Slavonic and East European Studies, for his assistance in making available Sir Bernard Pares' Papers; to the administration of the Finnish state Archives for granting access to the Baron A.F. 
Meyendorff Papers; to the staff of the National Archives Division in Washington; and to the Helsinki University Library.

I thank the Editor of The Russian Review for permission to publish here substantial portions in slightly modified form of my article 'The Workers' Groups and the War-Industries Committees: Who Used Whom?' which appeared in the April 1980 issue.

The number of people with whom I have discussed this work and from whom I have learned is great. Special thanks, with the usual exoneration from responsibility for errors, must go to Dr Harry Shukman, the supervisor of my Oxford D.Phil., and to Professors Leopold Haimson, Tsuyoshi Hasegawa, Diane Koenker, Daniel Orlovsky and Hans Rogger. I should also like to acknowledge the encouragement I have received from Archie Brown and Michael Kaser, both of St Antony's College, Oxford, and from Lyn Solotaroff of the Russian Institute at Columbia University.

Lastly, this book has a particular personal significance. Had it not been for the WarIndustries Committees, or rather the research undertaken in Helsinki a decade ago, I should not have met Leena. 


\section{Special Notes}

1. Events occurring in Russia before February 1918 are given in the Julian calendar which in the twentieth century was thirteen days behind the Gregorian calendar used in the West; events occurring after February 1918 (when Russia adopted the Gregorian calendar) are given according to the Gregorian calendar. Where a Western source is citeci, both dates are given.

2. The system of transliteration used throughout is that of the Library of Congress minus the diacritical marks. The only exceptions are names of foreign origin which had been Russianized. Thus, I refer to Stuermer rather than Shtiumer; Hermonius and not Germonius; Singer not $\mathrm{Zinger.}$

3. The orthography has been modernized to conform to the system in use in the Soviet Union.

4. The following Russian units in their English and American equivalents are:

1 pud $=361 \mathrm{~b}$ or $16.38 \mathrm{~kg}$

1 ruble $=f 0.10$ (July 1914)

1 verst $=0.66 \mathrm{miles}$ or $1.06 \mathrm{~km}$

1 arshin $=28$ inches $(0.71$ metre) 


\section{List of Abbreviations}

Institutions, Organizations and Archival Sources

Fo Foreign office (British)

GAU Glavnoe Artilleriiskoe Upravlenie (Main Artillery Administration)

GBIL Gosudarstvennaia Biblioteka imeni Lenina (Lenin Library)

GIU Glavnoe Intendantskoe Upravlenie (Main Quartermaster Administration)

GVTU Glavnoe Voenno-Tekhnicheskoe Upravlenie (Main Engineering Administration)

TsGAGM Tsentral'nyi Gosudarstvennyi Arkhiv Goroda Moskvy (Central State Archive of the City of Moscow)

TsGAOR Tsentral'nyi Gosudarstvennyi Arkhiv Oktiabr'skoi Revoliutsii (Central State Archive of the October Revolution)

TsGIA Tsentral'nyi Gosudarstvennyi Istoricheskif Arkhiv (Central State Historical Archive)

TsGVIA Tsentral'nyi Gosudarstvennyi VoennoIstoricheskii Arkhiv (Central State Military History Archive)

TsVPK Tsentral'nyi Voenno-Promyshlennyi Komitet (Central War-Industries Committee)

VPK Voenno-Promyshlennyi Komitet (War-Industries Committee). 
Published Sources

\begin{tabular}{|c|c|}
\hline$A R R$ & Arkhiv russkoi revoliutsii \\
\hline IZ & Istoricheskie zapiski \\
\hline$K A$ & Krasnyi arkhiv \\
\hline$P T$ & Promyshlennost' $i$ Torgovlia \\
\hline $2 h O S O$ & $\begin{array}{l}\text { Zhurnaly osobogo soveshchaniia dlia } \\
\text { obsuzhdeniia i ob"edineniia meropriiatii } \\
\text { po oborone gosudarstva (0soboe soveshcha- } \\
\text { nie po oborone gosudarstva), } 1915-1918 \mathrm{gg} \text {. }\end{array}$ \\
\hline
\end{tabular}

